\author{
Joanna Kowalczyk-Anioł \\ https:// orcid.org/0000-0002-1547-9304 \\ 1. Uniwersytet Łódzki \\ Wydział Nauk Geograficznych \\ Instytut Geografii Miast i Turyzmu \\ 2. CiTUR Centre for Tourism Research, Development and Innovation, Portugalia \\ joanna.kowalczyk@geo.uni.lodz.pl
}

\title{
HIPERTROFIA TURYSTYKI MIEJSKIEJ - GENEZA I ISTOTA ZJAWISKA
}

\begin{abstract}
Abstrakt: W artykule zaprezentowano autorskie ujęcie hipertrofii turystyki miejskiej, jak i genezę tego zjawiska w kontekście przemian współczesnego miasta. Przedstawiono, na podstawie literatury, logikę włączania i wykorzystywania turystyki w transformacji miejskiej gospodarki i przestrzeni oraz przypisane jej role w polityce miejskiej. Pokazano ponadto w różnych kontekstach geograficznych procesy i zjawiska towarzyszące współczesnej turystyfikacji miasta, w tym zyskującą na znaczeniu finansjalizację zasobów mieszkaniowych.

Słowa kluczowe: turystyka miejska, miasto postindustrialne, turystyfikacja, miejska przedsiębiorczość, rewitalizacja.

\section{URBAN TOURISM HYPERTROPHY - THE ORIGIN AND ESSENCE OF THE PHENOMENON}

Abstract: The article shows the author's concept of urban tourism hypertrophy as well as the genesis of this phenomenon in the context of transformation of the modern city. Based on literature, the logic of rooting and using tourism in the transformation of the urban economy and the transformation of the urban space, as well as the roles assigned to tourism in urban policy has been clarified. Also, the processes and phenomena accompanying the current stage of tourismification of the city, in various geographical contexts, have been discussed. In particular, the growing importance of tourism-related housing financialization was highlighted.

Keywords: urban tourism, postindustrial city, tourismification, urban entrepreneurialism, urban regeneration.
\end{abstract}

\section{WPROWADZENIE}

Miasta podlegają stałym wielowymiarowym przeobrażeniom wynikającym m.in. z procesów rozwoju cywilizacyjnego. Ich współczesna transformacja, ale też umacnianie pozycji w skali globalnej, regionalnej czy lokalnej, postępuje zarówno w warunkach restrukturyzacji, globalizacji, neoliberalnego zwrotu w rozwoju społeczno-gospodarczym, jak i ostatnio coraz częściej dyskutowanej finansjaliza$\mathrm{cji}^{1}$ (m.in. Aalbers, 2019a; Harvey, 1989; Sagan, 2017; Soja, 2004). W dwóch ostatnich dekadach XX w. $\mathrm{w}$ wielu miastach do sił i procesów transformujących dołączyła turystyka - rozwijana w sposób planowy, ale też coraz częściej (zwłaszcza w drugiej dekadzie XXI w.) niekontrolowany. Stała się ona istotnym elementem miejskiej dynamiki, który przyniósł wielorakie możliwości oraz wyzwania.

Miasto jest złożonym systemem, który funkcjonuje $\mathrm{w}$ zmiennych warunkach. Współcześnie coraz bardziej intensywnie ${ }^{2}$ uwidacznia się $w$ nim glo- balno-lokalne kontinuum przemian warunkowanych lokalnym kontekstem. Także napięcia i konflikty między globalnością i lokalnością ujawniają się w pierwszej kolejności właśnie w miastach (Sassen, 2007). Turystyka, której przypisuje się dziś status podstawowej praktyki społecznej nowoczesnego społeczeństwa (Sharpley, 2018), a zarazem duże znaczenie $\mathrm{w}$ globalnym wzroście konsumpcji, staje się nośnikiem tychże napięć. W szczególności jest nim turystyka miejska, będąca jednym z najszybciej rozwijających się segmentów globalnego rynku turystycznego (UNWTO, 2018).

Z perspektywy miasta nadrzędnym celem stymulowania turystyki jest jego społeczno-gospodarczy rozwój (Żabińska, 2013). Według UNWTO (2018) turystyka jest dziś wręcz motorem rozwoju miast, jakkolwiek nie powinna być jedynie "strategią dostarczania konkurencyjnego produktu spełniającego oczekiwania odwiedzających, lecz 
sposobem na rozwój samego miasta oraz zapewnienia większej i lepszej infrastruktury oraz warunków dla mieszkańców" (UNWTO, 2012, s. 7). Wzrost ruchu turystycznego, ale też inwestycji w turystykę miejska, spowodował jej kontestację wśród mieszkańców wielu miast, szczególnie europejskich. Uwidoczniła się ona zwłaszcza tam, gdzie masowa turystyka znacząco pogorszyła warunki i jakość życia lokalnych społeczności, co ilustrują m.in. przykłady z Wenecji, Barcelony, Lizbony, Amsterdamu czy Berlina (m.in. Colomb, Novy, 2017; Kowalczyk-Anioł, Zmyślony, 2017; Peeters i in., 2018). Implikacje tego zjawiska pobudziły dyskusję nad naturą współczesnego miasta turystycznego. Za jej meritum można uznać potrzebę bilansowania korzyści i kosztów rozwoju turystyki w mieście, a przede wszystkim społeczne ich szacowanie w perspektywie korzyści i kosztów odczuwanych przez mieszkańców.

Celem napisania niniejszego artykułu jest przybliżenie autorskiego ujęcia „hipertrofii turystyki miejskiej" (HTM) i omówienie genezy tego zjawiska. Opracowanie ma charakter koncepcyjny i zostało przygotowane na podstawie literatury przedmiotu. Składa się z trzech zasadniczych części. Pierwsza pokazuje genezę hipertrofii turystyki miejskiej w odniesieniu do wybranych aspektów przemian współczesnego miasta i roli, jaką odgrywa w nich turystyka. Druga część przedstawia istotę zjawiska hipertrofii turystyki miejskiej, a ostatnia stanowi podsumowanie.

\section{PRZEMIANY WSPÓ ŁCZESNEGO MIASTA (WYBRANE ASPEKTY) A TURYSTYKA - GENEZA HIPERTROFII TURYSTYKI MIEJSKIEJ}

Jak zaznaczono we wstępie współczesne miasta podlegają stałym przeobrażeniom związanym z postindustrialnym etapem ich rozwoju. Spośród tendencji istotnych dla kształtowania przestrzeni i dynamiki dzisiejszych miast wiele wiąże się bezpośrednio lub pośrednio $\mathrm{z}$ procesami ich turystyfikacji ${ }^{3}$. Należą do nich m.in. restrukturyzacja bazy ekonomicznej miasta, reorganizacja przestrzeni miejskiej (zwłaszcza jego inner city) oraz zmiany w kulturze wizualnej miasta sprzyjające tworzeniu przestrzeni ludycznych (rozrywki i kultury) i przestrzeni konsumpcji (które Harvey sugestywnie na- zywa tworzeniem „globalnego banku obrazów”). Wśród zmieniających się funkcji miejskich rosnące znaczenie zyskały takie, które związane są ze spędzaniem wolnego czasu (w tym turystyką), życiem kulturalnym i rozrywką ${ }^{4}$ (m.in. Lloyd, Clark, 2001; Mullins, 1991). Mają one w dużym stopniu charakter funkcji egzogenicznych, skierowanych do zewnętrznych użytkowników miasta (Martinotti, 1993). Stanowią zarówno wspomnianą podstawę przezwyciężania problemów związanych z utratą bazy ekonomicznej, modernizacji miejskiej gospodarki zorientowanej na konsumpcje, jak i marketingu skupionego na tworzeniu nowego pozytywnego wizerunku i potencjału konkurencyjności miasta rywalizującego o inwestorów, mieszkańców, studentów, odwiedzających (m.in. Bradley, Hall, Harrison, 2002; Kaczmarek, 2010; Richards, 1996).

Do obserwowanych powszechnie praktyk, które znacząco wpłynęły na omawiane w artykule kierunki transformacji sprzyjające rozwojowi turystyki należą zwłaszcza adaptacja miejskiej przedsiębiorczości jako modelu zarządzania miastem (Harvey, 1989) oraz rewitalizacja (szczególnie obszarów centralnych) przez kulturę (Bianchini, 1993). Lloyd i Clark (2001) oraz Hoffman, Fainstein i Judd (2003) wskazują również bezpośrednio przyjmowaną w wielu przypadkach turystyfikację jako miejską strategię rozwoju gospodarczego. Każdy z tych wzorców zarządzania przestrzenią miejską w mniejszym lub większym stopniu sprzyjał i wciąż sprzyja wzrastającej roli turystyki w mieście i przyczynił się do jej współczesnej rangi w kształtowaniu i wykorzystaniu miejskiej przestrzeni. W skrajnych przypadkach (np. miast hiszpańskich - Blazquez-Salom, Blaneo-Romero, Vera-Rebollo, Ivars-Baidal, 2019; Russo, Scarnato, 2018) można mówić o praktykowanym boosteryzmie w podejściu do planowania rozwoju turystyki, który opiera się na przekonaniu, że stymulowanie popytu turystycznego ma korzyści rozwojowe przewyższające koszty (Hall, 2008). Jak argumentował Harvey (1989) w swojej pracy na temat przedsiębiorczego miasta, turystyka może być ważną strategią budowania miejskiej reputacji i rywalizacji między miastami. Jego przewidywania okazały się w tym względzie trafne. Turystyka miejska upowszechnia ,konsumpcję przyjemności" (Mullins, 1991) i współtworzy konsumpcyjną miejską kulturę (Błaszczyk, 2015; Selby, 2004). Jest powszechnie wykorzystywana zarówno w tworzeniu wizerunku miast (Bradley, Hall, Harrison, 2002; Lucarelli, Berg, 2011), jak i współzawodnictwie między miastami. Jednakże odczuwane współcześnie konsekwencje nadmiernego entuzjazmu 
i często leseferystycznego podejścia do rozwoju turystyki, skłoniły liczne miasta do poszukiwania bardziej zrównoważonych, a nawet postwzrostowych rozwiązań (Blazquez-Salom, Blaneo-Romero, Vera-Rebollo, Ivars-Baidal, 2019; np. PEUAT - restrykcyjny plan urbanistyczny dotyczący zakwaterowania turystycznego w Barcelonie z 2017 r.; PIAT - plan interwencji na obszarach turystycznych na Majorce z 2018 r.). Żeby zrozumieć skalę i zakorzeniony $\mathrm{w}$ naturze miasta charakter tych wyzwań uzasadnione wydało się zgłębienie związków turystyki z miejską transformacją końca $X X$ i początku XXI w. Uwagę skupiono na (wcześniej już wzmiankowanych) trzech, zdaniem autorki najważniejszych, aspektach - dominującym modelu polityki miejskiej, rewitalizacji miejskich centrów oraz pozostającym $\mathrm{z}$ nimi w bezpośredniej relacji obserwowanym zmieniającym się charakterze procesów turystyfikacji miasta.

\subsection{MIEJSKA PRZEDSIĘBIORCZOŚĆ JAKO MODEL POLITYKI MIEJSKIEJ}

Istotnym uwarunkowaniem przemian miasta końca $X X$ w. i konstytuowania roli turystyki w tej transformacji była obecna od lat 80 . XX w. rosnąca presja racjonalizowania wydatków publicznych. Przyczyniła się ona do zmiany modelu polityki miejskiej z administracyjnej na miejską przedsiębiorczość (Harvey, 1989; Sagan, 2017), zachodzącej głównie pod wpływem rosnącej rywalizacji między miastami. Jak podkreśla Sagan (2017, s. 38), „pierwszoplanową rolę $\mathrm{w}$ tej transformacji odegrały kształtujące się na zasadach przedsiębiorczości: kultura, kapitał społeczny, innowacyjne środowisko, sieciowe powiązania, strategiczne alianse, partnerstwo publiczno-prywatne". Współczesne doktryny polityki miejskiej nakazują udział w konkurencyjnej przedsiębiorczości oraz podporządkowanie się wymogom kreatywności i innowacyjności. Te ostatnie wydają się być od zawsze wpisane w naturę miasta (Stryjakiewicz, 2010). Jednakże dziś czynnikiem odpowiedzialnym za utrzymywanie ekonomicznej kondycji i konkurencyjności miast, zwłaszcza wielkich (i z turystycznymi ambicjami - dopowiada Paskaleva-Shapira, 2007), stało się coraz większe tempo dostarczania innowacji (Madurowicz, 2017). Jessop (2015, s. 86) wskazuje, że „innowacyjność i przedsiębiorczość miejska tworzą rodzaj ruchomej bieżni, na której na korzyści płynące $\mathrm{z}$ innowacji czyhają (konkurencyjne - autor) miasta", które naśladują pionierów i seryjnie powielają rozwiązania (por. tzw. efekt Bilbao). Mechanizm ten, zauważa trafnie Harvey (1989), wymaga stałej modyfikacji przestrzeni miejskiej, co rodzi rzeczywiste głębokie problemy spoleczne i gospodarcze (przypadek Barcelony - m.in. Kowalczyk-Anioł, Zmyślony, 2017). Wskazuje również (podobnie Hall, 2006; Keil, 2009) na coraz silniejsze związki miejskiej przedsiębiorczości $\mathrm{z}$ szerokim projektem neoliberalizmu. Ilustruje to Barcelona opisana przez Russo i Scarnato (2018) jako casus "neoliberalnego wzorca miasta turystycznego". Zdaniem tychże miasto to "ustanowiło cnotliwy i stabilny reżim synergii ze swoją turystyką" (Russo, Scarnato, 2018, s. 4), z którego z literą prawa (umiejętnie wykorzystane w tym celu planowanie strategiczne) „usunięto wszelkie 'gorsety' społeczne i fizyczne utrudniające tworzenie środowiska przyjaznego turystyce" (ibidem, s. 5).

Jak zauważa Sagan (2017), model miejskiej przedsiębiorczości realizują zarówno kraje, które przeszły demokratyczną transformację, jak i te, które przeprowadzily liberalizację gospodarki (np. Chiny). Podkreśla również częstą bezkrytyczną imitację tego wzorca, widoczną w trajektoriach zmian polityki miejskiej w krajach, które w ostatnich dekadach przyjęly neoliberalny model gospodarki. Jednocześnie wskazuje, że do głównych (najczęściej wymienianych w literaturze) cech miejskiego neoliberalizmu, obok instytucjonalizacji międzymiejskiej konkurencji, opierając się na logice ryn$\mathrm{ku}$, należy też wzrost polaryzacji miejskich zbiorowości. Obie własności znajdują odzwierciedlenie w opisywanych w literaturze przykładach z coraz większej liczby miast turystycznych (m.in. Arbaci, Tapada-Berteli, 2012; Blazquez-Salom, Blaneo-Romero, Vera-Rebollo, Ivars-Baidal, 2019; Cocola-Gant, Gago, 2019; Russo, Scarnato, 2018; Vives Miró, 2011). Obserwowany w nich pobudzony turystyką wzrost gospodarczy nie jest inkluzyjny, lecz prowadzi do pogłębiania rozwarstwienia społecznego, w tym marginalizacji i wykluczenia znaczących grup społecznych (przykładów dostarcza m.in. Lizbona, Sewilla i Barcelona). Jednocześnie $\mathrm{w}$ wielu miastach udział turystyki (w dochodzie i zatrudnieniu w szeroko rozumianym sektorze turystyki i hotelarstwa) w tym wzroście jest na tyle znaczący, że doprowadził do nieobecnej dotychczas w europejskich dużych miastach sytuacji dylematu miejskiego w postaci wykształcenia sprzężenia zwrotnego typu „zbyt duży by upaść” (toobig-to-fail - TBTF). 


\subsection{REWITALIZACJA MIEJSKIEGO CENTRUM}

Ważnym czynnikiem wzrostu atrakcyjności turystycznej miasta są przemiany miejskiej przestrzeni związane z ich rewitalizacją (Amore, 2019; Kaczmarek, 1999), szczególnie te obserwowane na obszarach śródmiejskich (Spirou, 2011). Rewitalizacja miejskich centrów rozpoczęła się w latach $70 . \mathrm{XX} \mathrm{w}$. i trwa nadal (m.in. Lowe, 2005; Smith, 1986; Spirou, 2011). Trend ten zdominował miejską politykę rewitalizacyjną i, zdaniem Sagan (2017), jest dziś ściśle związany $\mathrm{z}$ koncepcją neoliberalnego rozwoju miasta. Ukierunkowana rynkowo polityka miejska uprzywilejowuje bowiem praktyki zorientowane na odnowę atrakcyjnych, dobrze zlokalizowanych obiektów i obszarów mających rynkowy potencjał, czyli zwykle centralnej (historycznej) dzielnicy miasta. Społeczne wartościowanie tej przestrzeni, często jako przestrzeni tożsamości, o sentymentalnym i symbolicznym wymiarze, a także względy prestiżowe sprzyjają biznesowej oraz politycznej koncentracji uwagi na wspomnianych obszarach śródmiejskich $^{5}$ (m.in.: Hubbard, 1996; Sagan, 2017). Smith (2005), komentując skalę rewitalizacji i towarzyszącej jej gentryfikacji, mówi wręcz o legitymizowanych projektami rewitalizacji procesach podboju miejskich centrów pod koniec $X X \mathrm{X}$.

Od lat 90. XX w. obserwowany jest zwłaszcza triumf projektów rewitalizacji miasta przez kulturę (Bianchini, 1993; Smith, 2006; Zukin, 2009). Jak zauważa Murzyn (2006), kwestię zachowania autentyczności konfrontowano $\mathrm{z}$ dążeniem do stworzenia estetycznego otoczenia. Ostatecznie częstokroć ważniejsze było wytworzenie „przyjemnego doświadczenia miejskości" (Murzyn, 2006; Salah Ouf, 2001), jakkolwiek widoczne są również przykłady przesadnie akcentowanego dziedzictwa $\mathrm{w}$ miejskiej przestrzeni. $W$ wielu miastach poprawianie estetyki łączono z kreowaniem przestrzeni rozrywki, zabawy i wrażenia niekończącego się karnawału (tzw. festival marketplace - Hughes, 1999). Tak przeprowadzana miejska odnowa jest ściśle związana z założeniami gospodarki kulturowej (Scott, 1997) zamieniającej przestrzeń miasta, dobro kultury $\mathrm{w}$ dobro rynkowe, a miejski krajobraz kulturowy $\mathrm{w}$ tzw. tourismscape (Jansen-Verbeke, 2009). Towarzyszy jej instrumentalizacja, prywatyzacja i komodyfikacja (utowarowienie) dziedzictwa, zwłaszcza historycznych miejskich centrów (Purchla, 2018). Jak konstatuje Scott (2000), kultura jest dużym biznesem zakorzenionym szczególnie w globalnej praktyce projektów miejskiej rewitalizacji. Jednocześnie takie przedsięwzięcia stymulują turystykę, gdyż „kultura i komercja są wyraźnie ze sobą powiązane w ponowoczesnym świecie globalnej konsumpcii" (Smith, 2006, s. 2). Według Amore (2019) kwintesencją rewitalizacji obszarów miejskich są rozmaite typy krajobrazów turystycznych wykreowanych w mieście - od rekonstrukcji historycznych centrów miast, projektów dzielnic biznesowych, rewitalizacji nabrzeży i obszarów przemysłowych po projekty flagowe (Muzem Guggenheima w Bilbao), jak i związane z organizacją rozmaitych wielkoskalowych wydarzeń (zob. też: Bianchini, Dawson, Evans, 1992; González, 2011; Hiller, 2000; Park, 2013; Smith, 2012). Są one istotnymi elementami wizerunków miast zaciekle ze sobą konkurujących oraz trzonem miejskiej „,architektury konsumpcji” (Mullins, 1991, s. 331), która „sygnalizuje możliwości przyjemności" (konsumpcji przyjemności) skierowanej do wszystkich użytkowników miasta. Jak bowiem trafnie zaznacza Spirou (2011), strategie rewitalizacji inner city przez kulturę podsycało rosnące zainteresowanie mieszkańców i obserwowana $\mathrm{u}$ nich (zwłaszcza u młodych) skłonność do zwiększania wydatków na czas wolny - por. Mullins (1991). Działania te, którym towarzyszył wzrost ruchu turystycznego, sprzyjały $\mathrm{z}$ kolei tworzeniu miejsc pracy, zwłaszcza w tzw. leisure amenities/ facilities, czyli udogodnieniach, infrastrukturze atrakcyjnej do spędzania czasu wolnego (Clark, Lloyd, Wong, Jain, 2002; Judd, 2015) oraz przyciągały zarazem młodych ludzi do centrum. Jednocześnie, jak wskazuje Spirou (2011), obserwowane od samego początku (m.in. w Baltimore już w latach 80. XX w.) niektóre implikacje wzrostu tak pobudzanej turystyki zawierały wątpliwe dla miasta społeczne i gospodarcze korzyści. Ujawniały m.in. problemy związane z funkcjonowaniem swoistego miasta dualnego (obsługującego gości i mieszkańców), jak i systemu, który dąży do wspierania interesów elit korporacyjnych (por. też: Gotham, 2005; Russo, Scarnato, 2018).

W dyskursie o rewitalizacji miast europejskich zorientowanych na rozwój turystyki podkreślane są związki z funduszami unijnymi (Morell, 2009). Jednocześnie, jak zauważył Hall (1993), kształtowany projektami kulturalnymi o statusie międzynarodowym wizerunek miast europejskich stał się jedną z głównych sił definiujących nową hierarchię miast w globalizującej się europejskiej gospodarce. Utrwalił też na arenie światowej markę europejskich miast dziedzictwa i budowaną na niej przewagę konkurencyjną Europy jako regionu turystycznego. Można też mówić o ewolucji europejskiego podejścia do rewitalizacji (zależnej częściowo od sytuacji ekonomicznej i politycznej poszczególnych krajów). 
Postępowała od odnowy materialnej tkanki miejskiej, przez rewitalizację ukierunkowaną na rynek (zwłaszcza nieruchomości) i inwestycje kulturalne, po eksponowanie społeczności lokalnych i potrzeby partnerstwa między sektorem publicznym, prywatnym i pozarządowym (Murzyn, 2006). W ostatniej dekadzie można ponadto wskazać projekty np. w Hiszpanii, dla których katalizatorem stał się kryzys końca I dekady XXI w. (Blazquez-Salom, Blaneo-Romero, Vera-Rebollo, Ivars-Baidal, 2019)6. W Polsce i innych krajach postsocjalistycznych nakładające się procesy transformacji ustrojowej i przemian postindustrialnych sprawily, że charakter miejskiej rewitalizacji był początkowo mniej intensywny, często niewystarczająco skoordynowany przez restytuowane samorządy (Murzyn, 2006). Towarzyszyły jej liczne bariery, w tym niejasności legislacyjne i konflikty interesów (Kaczmarek, 2001). W tych krajach, jak zauważa Amore (2019), rewitalizacja wprowadzana po 1990 r. jako agenda rynkowa promowała tworzenie $\mathrm{w}$ historycznych centrach ekskluzywnych enklaw dla turystów i zamożniejszych city users - m.in. w Pradze (Cook, 2010), Tallinnie (Stanilov, 2007), Krakowie (Murzyn-Kupisz, 2012).

Rozpoczęta 40 lat temu od Inner Harbor w Baltimore w Stanach Zjednoczonych (uznany w literaturze za pierwszy $\mathrm{w}$ historii projekt rewitalizacji przez turystykę - Bianchini, Dawson, Evans, 1992) globalna dyskusja nad wykorzystaniem turystyki w miejskiej odnowie oraz rozwoju była i jest burzliwa (m.in. Amore, 2019; Bianchini, 1993; Blazquez-Salom, Blaneo-Romero, Vera-Rebollo, Ivars-Baidal, 2019; Eisinger, 2000; González, 2011; Gotham, 2005; Hubbard, 1996; Judd, 1999; Richards, Wilson, 2006) i wydaje się wciąż niewyczerpana. Jej nieodłącznym elementem jest gorąca polemika wokół związków rewitalizacji z gentryfikacją, w której turystyce przypisano dużą i stale rosnącą siłę sprawczą, co szeroko omówiła Kowalczyk-Anioł (2018). Podsumowując trzeba zaznaczyć, że rewitalizacja miejskich obszarów zmierzająca do wykreowania przestrzeni rekreacyjno-turystycznych jest nadal aktualna wśród miejskich celów (Amore, 2019; Darchen, 2013).

\subsection{CHARAKTER MIEJSKIEJ TURYSTYFIKACJI}

Jak już pokazano obserwowana od lat 80 XX. w. turystyfikacja miast stała się globalnym fenomenem. Początkowe etapy tego zjawiska, zwłaszcza na gruncie europejskim, były związane $z$ transformacją (według opisanych wcześniej mechanizmów) walorów kulturowych, krajobrazu kulturowego oraz przestrzeni publicznej pod kątem potrzeb i oczekiwań odwiedzających (Jansen-Verbeke, 1998, 2009) i dokonywane ze znaczącym udziałem władz państwowych i municypalnych w tych działaniach (zobacz też Dziedzic, 2012). Obecne stadium - tzw. turystyfikacja codzienności/codziennego życia (Bourdeau, François, Bensahel, 2013) - jest związane z wkraczaniem turystyki (tzw. turystyki poza utartym szlakiem - Maitland, Newman, 2014) w dotychczas nieturystyczne sfery miejskiego życia: przestrzenie aktywności mieszkańców (np. rynki, pchle targi - Gravari-Barbas, Jacquot, 2019); przestrzenie zamieszkania (prywatne domy, domy studenckie), czy praktyki społeczne (jazda na rowerze, gotowanie) - rys. 1.

\section{$\left.\left.\left.\sum \begin{array}{c}\text { Turystyfikacja } \\ \text { walorów i krajobrazu } \\ \text { kulturowego }\end{array}\right\rangle \begin{array}{c}\text { Turystyfikacja } \\ \text { przestrzeni } \\ \text { publicznej }\end{array}\right\rangle \begin{array}{c}\text { Turystyfikacja } \\ \text { życia } \\ \text { codziennego }\end{array}\right\rangle$ \\ Rys. 1. Fazy turystyfikacji miasta Źródło: autorka}

W pewnym stopniu agentami takiej turystyfikacji są mieszkańcy i turyści. Początkowo niszowa w środowisku miejskim turystyka poza utartym szlakiem (off the beaten track) oraz formuła peer to peer krótkoterminowego najmu turystycznego opierająca się na idei współdzielenia7, która pozwala mieszkańcom na udostępnianie turystom niewykorzystanych zasobów za pośrednictwem platform internetowych (Pawlusiński, 2017), tworzyły alternatywną ofertę miasta oraz możliwości podjęcia nowej aktywności i zyskanie dodatkowego dochodu dla stałych rezydentów. Jednakże w drugiej dekadzie XX w. umasowieniu turystyki miejskiej często towarzyszy wypaczanie idei współdzielenia (w odniesieniu do krótkoterminowego najmu zasobów mieszkaniowych - Belk, 2014) oraz jej ewolucja do trudnej w regulacji i częstokroć wrogiej interesom mieszkańców ${ }^{9}$ formy tzw. platformowego kapitalizmu (Aalbers, 2019a). W tym sensie obserwowaną turystyfikację życia codziennego stymuluje działalność globalnych komercyjnych platform rezerwacyjnych typu Airbnb. Dwuznaczne oblicze turystyfikacji codzienności to z jednej strony wspomniana aktywność turystów podejmowana w poszukiwaniu autentyczności (nawiązując do dewizy Airbnb: living like a local), przekraczająca przygotowaną turystyczną bańkę (Judd, 1999), z drugiej strony natomiast związane $\mathrm{z}$ nimi następstwa od- 
czuwane przez mieszkańców w „splocie gentryfikacji - turystyfikacji - finansjalizacji" (Aalbers, 2019a). Wspomniane, coraz silniej sprzęgnięte ze sobą, procesy przeobrażają lokalne sąsiedztwa, mieszkalnictwo i rynek nieruchomości. Napędzana krótkoterminowym najmem turystycznym finansjalizacja rynku mieszkaniowego przez globalnych graczy jest obserwowana w coraz większej liczbie miast rozwiniętych gospodarek. Jest ona nowym wymiarem finansjalizacji globalnej gospodarki rynkowej, która powiązała rosnący popyt turystyczny $\mathrm{w}$ miastach $\mathrm{z}$ atrakcyjnością inwestycji kapitałowych w nieruchomości, zwłaszcza mieszkaniowe. Jej konsekwencją jest drastyczne ograniczenie dostępności najmu długookresowego dla rezydentów odczuwane od Nowego Jorku przez Dublin, Utrecht, Lizbonę, Barcelonę, po Berlin i Tokyo (m.in. Aalbers, 2019a, b; Ioannides, Röslmaier, van der Zee, 2019; Wachsmuth, Weisler, 2018). Casus lizbońskiej Alfamy pokazuje, że pokryzysowa liberalizacja przepisów najmu i ułatwienia inwestycji w nieruchomości mieszkaniowe obcokrajowcom uruchomily intensywny proces typu „kupno na wynajem” (buy-to-let investment), którego reperkusjami są głębokie zmiany społeczno-przestrzenne tej historycznej dzielnicy. Zdaniem Cocola-Gant i Gago (2019) ${ }^{10}$ nastąpiło masowe i gwałtowne wyparcie mieszkańców i lokalnej działalności turystycznej oraz przekształcenie żywej tkanki miejskiej (i współtworzących muzyczny genius loci Lizbony casas de fado - lokali z muzyką fado $\left.{ }^{11}\right)$ w pozbawioną żywotności i autentyczności przestrzeń dla turystów (zob. też Lestegás, Seixas, Lois-González, 2019).

Wzmożona (i trudna w kontroli) presja globalnie dostępnego turystycznego najmu za pośrednictwem platform typu Airbnb czy booking.com, ale też innych form zakwaterowania turystycznego (hosteli, hoteli) wychodzi poza tradycyjne dzielnice aktywności turystycznej (pochłaniając np. barcelońską robotniczą Barcelonetę). Współtworzy zarazem kolejną falę gentryfikacji - wzmocnioną uciążliwościami tzw. nocnej gospodarki ${ }^{12}$, która pogłębia problemy obszarów śródmiejskich, zwłaszcza w dobrze skomunikowanych atrakcyjnych europejskich miastach z szeroką ofertą rozrywkową (m.in. Jover, Diaz-Parra, 2020; Kruczek, 2018; Pinkster, Boterman, 2017). Dotyczy ona w szczególności konkurencyjnych cenowo miast środkowoeuropejskich (Praga, Budapeszt, Kraków), miast hiszpańskich i portugalskich, ale też Berlina czy Amsterdamu. Przypadek tego ostatniego pokazuje, że także zamożni przedstawiciele klasy średniej (wcześniejsi gentryfierzy), pod presją rosnących uciążliwości masowej turystyki, opuszczają swoje posiadłości w Canal District. Gravari-Barbas (2017) dostrzega ponadto zjawisko tzw. hiperturystyfikacji, którą napędza globalny kapitał, a sankcjonuje leseferystyczne podejście władz lokalnych do turystyki. Jej emanacją jest tworzenie wyrafinowanej, luksusowej przestrzeni turystycznej (np. w paryskiej Le Marais) wypreparowanej z tkanki społecznej miasta kolejnymi falami gentryfikacji. Uwzględniając genezę wymienionych przypadków można zatem wskazać różne trajektorie formowania turystycznej przestrzeni ekskluzji (wyparcia). Jover i Diaz-Parra (2020), na przykładzie historycznego centrum Sewilli13 ${ }^{13}$ pokazują, że gwałtowny wzrost liczby turystów i napływ tzw. lifestylowych migrantów uczynił tę przestrzeń zaledwie $\mathrm{w}$ kilka ostatnich lat niedostępną dla przeciętnego sevillano, przestrzenią całkowicie wyłączającą lokalnych mieszkańców z jej użytkowania.

Przedstawiona na podstawie literatury sprawcza obecność turystyki w przemianach i rozwoju miasta postindustrialnego ma różną skalę i różne skutki. Widoczna jest zarówno szczególna łatwość wkomponowywania się turystyki $\mathrm{w}$ dynamikę przemian miasta, jak i rozmaitość kształtowanych powiązań i mechanizmów oddziaływania. O ile rozwój turystyki miejskiej i transformacja miasta są bez wątpienia wzajemnie konstytuującymi się procesami, o tyle zdumiewa asymetria obserwowanych korzyści, zwłaszcza brak przełożenia na poprawę kondycji społecznej miasta, a w skrajnych przypadkach nawet destrukcja tkanki społecznej turystyfikowanych przestrzeni. Można zatem stwierdzić, że:

a) rozwój turystyki miejskiej ewoluował $w$ wielu miastach $\mathrm{z}$ kategorii szans do kategorii miejskich zagrożen, zwłaszcza $\mathrm{w}$ wymiarze społecznym;

b) w wielu miastach turystyka zaczyna być postrzegana jako czynnik, który wzmacnia rozziew między ich kondycją ekonomiczną i kondycją społeczną;

c) można mówić o różnych wymiarach i fazach turystyfikacji miasta;

d) rozwojowi turystyki miejskiej towarzyszy wiele zjawisk i procesów coraz silniej z nią sprzęgniętych, $w$ tym gentryfikacja i finansjalizacja;

e) można wskazać kilka typów kształtowania miejskiej przestrzeni turystycznej związanej $\mathrm{z}$ odmiennymi mechanizmami wyparcia lokalnej społeczności; 
f) ujawnia się także mechanizm przechwytywania nienależnych korzyści (rent seeking), zwłaszcza w kontekście korzyści z rewitalizacji, w której kosztach i wysiłku partycypowało miasto i mieszkańcy;

g) zakorzeniona w wielu miastach turystyka wydaje się zyskiwać status „zbyt dużej by upaść".

W świetle powyższego coraz śmielej odchodzi się w myśleniu o mieście jako systemie teleologicznym ${ }^{14}$, które - jak wskazuje Parysek (2015, s. 45): „funkcjonuje po to, aby zapewnić możliwie jak najlepsze warunki życia i obsługi mieszkańców. Jednocześnie jest systemem, w którym sprawczymi elementami jego funkcjonowania i rozwoju są właśnie jego mieszkańcy". Rodzą się też uzasadnione pytania: Jak zapewnić, by potencjał turystyki służył postępowi miasta, a nie destrukcji jego struktury społecznej? Jak monitorować negatywne skutki i presję turystyki miejskiej oraz narastające dysfunkcje? W powyższych kontekstach hipertrofia turystyki miejskiej (w tym także wszystkie jej symptomy) wymaga co najmniej uważnej obserwacji, jak i teoretycznej eksploracji.

\section{HIPERTROFIA TURYSTYKI MIEJSKIEJ - ISTOTA ZJAWISKA}

Zilustrowany jedynie częściowo charakter i skala współczesnej turystyki miejskiej skłaniają do refleksji. Obok niekwestionowanych pozytywnych skutków teraźniejszym wyzwaniem stają się negatywne implikacje rozwoju turystyki odczuwane przez mieszkańców. Signum témporis stanowią takie, które ujawniają się $\mathrm{w}$ dużych miastach rozwiniętych systemów społeczno-gospodarczych, w tym europejskich, kształtowanych w myśl doktryny neoliberalnej.

Obserwowane w wielu miastach zjawisko moż-

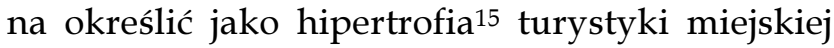
(HTM). Jest ona stanem zakłócenia ich homeostazy przez przerost funkcji turystycznych, który zagraża innym, zwłaszcza endogenicznym, funkcjom miejskim. Jest to jeden $\mathrm{z}$ niezrównoważonych stanów miasta ${ }^{16}$. Jeśli natomiast przyjmiemy, nawiązując do przywołanego wcześniej Paryska, że tym, co konstytuuje miasto pod względem społecznym, czyli kwintesencją miasta są stali mieszkańcy, to można również wskazać, że jej zaprzeczeniem (antytezą) jest miasto turystów „wypreparowane z mieszkańców"17. W tym sensie postępująca hi- pertrofia turystyki miejskiej może być interpretowana jako proces anihilacji miasta.

Hipertrofia turystyki miejskiej, tak jak wiele zjawisk i problemów miejskich ma charakter kontekstualny. Jednakże, co pozwalają przyjąć liczne replikacje, formowanie hipertrofii turystyki w warunkach miejskich wiąże się ze wzrostem konsumpcji jako globalnym modelem rozwoju i przeobrażeniami miasta, w których rozwój funkcji turystycznej był uprzywilejowany i zwykle niekontrolowany. Współcześnie uwidaczniają się kolejne procesy i mechanizmy, które oddziałują na skomplikowane relacje miasta i turystyki.

W nawiązaniu do teorii złożoności (Domański, 2017) można założyć, że hipertrofię turystyki miejskiej konstytuuje m.in. dynamika systemu, a jej cechy wyłaniają się z interakcji między różnymi aktorami (interesariuszami turystyki) oraz aktorami i przestrzenią. Aktualne podejście w naukach o turystyce i dyskusji nad rozwojem zrównoważonym odwołuje się do uwzględnienia interesów wszystkich aktorów turystyki, czy odnosząc się do określenia Freemana - wszystkich interesariuszy, w tym przypadku interesariuszy turystyki miejskiej (tourism stakeholders). Spośród głównych grup interesariuszy, czyli: przedsiębiorców i organizacji publicznych, władz lokalnych oraz środowiska i społeczności lokalnej, największym wyzwaniem jest uwzględnienie interesu ostatniej $\mathrm{z}$ wymienionych grup, czyli lokalnej społeczności, a zwłaszcza tej jej części, która nie jest zaangażowana w rozwój turystyki, a którą w codziennym życiu dotykają skutki i efekty zewnętrzne turystyfikacji miasta. Takie spojrzenie, wspiera argumentacja Izdebskiego ${ }^{18}$, który wskazuje, iż ,tak naprawdę prawa do miasta nie mają wszyscy mieszkańcy, tylko każdy ma prawo do tej części miasta, w której żyje, z której korzysta, która czyni go prawdziwym interesariuszem tego miasta"19 (Panel ekonomiczno-planistyczny..., 2014, s. 631). Proponowane ujęcie dowartościowuje dotychczas zaniedbaną perspektywę społecznej walidacji rozwoju turystyki miejskiej. Dla zrównoważenia faworyzowanego spojrzenia turysty (używając metafory zapożyczonej od Urry'ego) koncentruje się na spojrzeniu mieszkańca, a dokładniej mieszkańców turystyfikowanych obszarów miejskich. Przyjęto zatem, że zrozumienie społecznej percepcji skutków rozwoju turystyki miejskiej jest niezbędne, by racjonalnie dyskutować nad jej przyszłym kształtem i skutecznym mitygowaniem jej presji. Uwzględniono zarazem najczęściej wskazywane w literaturze negatywne skutki i dysfunkcyjne mechanizmy funkcjonowania turystyki miej- 
skiej (wymiary i sfery presji turystyki), które pogrupowano w odniesieniu do wpływu na:

- warunki i jakość życia;

- przestrzeń miasta;

- miejskie zasoby - bilans korzyści i kosztów, doświadczanie negatywnych efektów zewnętrznych;

- gospodarkę i zarządzanie.

W konsekwencji ujęcie HTM ma konstrukcję parasola (tzw. umbrella construct), która pozwala objąć (opisać i wyjaśnić) różne zjawiska, relacje i procesy (rys. 2). Na konceptualny parasol hipertrofii turystyki miejskiej składają się odczuwane przez mieszkańców:

- przesycenie miasta (zwykle jego historycznego centrum) turystami (i innymi odwiedzającymi, zwłaszcza jednodniowymi) oraz działalnością turystyczną, obniżające jakość życia w mieście i ograniczające korzystanie $\mathrm{z}$ jego zasobów;

- zakłócenie ładu przestrzennego, dominacja turystyki w przestrzeniach publicznych miast;

- przewaga miejskich kosztów nad korzyściami z rozwoju turystyki - nadmierna eksploatacja miejskich zasobów (negatywne skutki i efekty zewnętrzne społeczne, infrastrukturalne, gospodarcze, środowiskowe);

- ryzyko ograniczenia decyzyjności (podmiotowości $\mathrm{w}$ decydowaniu) i uzależnienia od zewnętrznych interesariuszy oraz uruchomienia błędnego koła zastoju społeczno-gospodarczego.

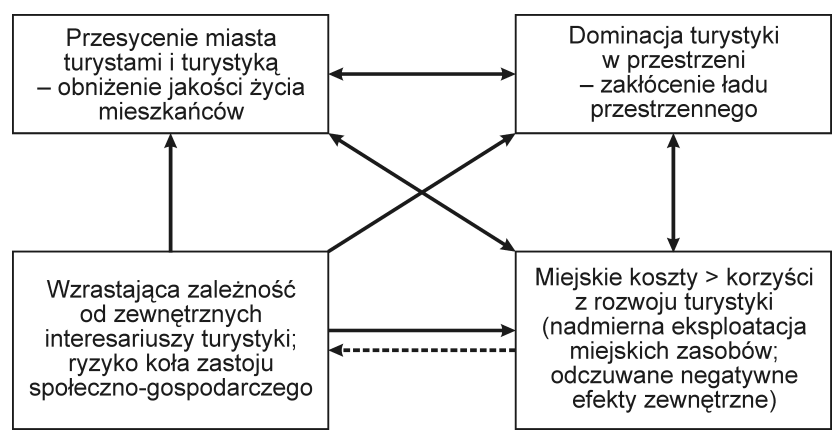

Rys. 2. Hipertrofia turystyki miejskiej - główne elementy i relacje

Źródło: autorka

Rozpatrując zaproponowany schemat hipertrofii turystyki miejskiej (rys. 2) warto zwrócić uwagę na kilka kwestii. Po pierwsze, uwzględnia on różne wymiary funkcjonowania miasta kluczowe z perspektywy mieszkańca pod względem podatności na oddziaływanie turystyki i które powinny stano- wić przedmiot uwagi w praktyce badawczej. Po drugie, prezentowany układ tworzą różne elementy (na różnych poziomach złożoności) i wielorakie relacje, opisywane różną siłą i wektorem działania. Po trzecie, układ ten stwarza przesłankę zarówno do zintegrowanego opisu i oceny społecznej percepcji wpływu turystyki miejskiej, jak i rozpoznania obszarów narastających dysfunkcji. Po czwarte, zaproponowana konstrukcja jest jednak jedynie uproszczonym opisem i interpretacją wybranych aspektów niezwykle złożonej rzeczywistości miejskiej. Mają one charakter dynamiczny i często niedookreślony. Sam zaś schemat powinien podlegać kontekstualnej rewizji.

W zaproponowanym ujęciu zwrócono uwagę na złożony wpływ turystyki na miasto i jego mieszkańców. Interpretację HTM inspirują także studia nad konfliktem. Jak zauważa Madurowicz (2017), konflikt jest elementem ciągłości miasta, częstokroć motorem jego rozwoju. Sytuację HTM konstytuuje skądinąd naturalny (choć nie zawsze ujawniony) konflikt między różnymi grupami aktorów funkcjonującymi w przestrzeni turystycznej miasta, interesariuszami turystyki miejskiej, czy wreszcie interesariuszami miasta. Jest to często konflikt o ograniczone zasoby, zwłaszcza przestrzeń miejską. Jakkolwiek przyczyn konfliktów może być znacznie więcej, to umiejętne ich rozpoznanie i zarządzanie tym wstępującym konfliktem miejskim staje się realnym wyzwaniem dla obszarów recepcji turystycznej (Kowalczyk-Anioł, Włodarczyk, 2017). $\mathrm{W}$ wielu przypadkach istotnym aspektem tego rodzaju miejskiej hipertrofii jest również mediatyzacja problemu oraz jego upolitycznienie (co pokazują przykłady z Barcelony, Wenecji i Berlina).

Podsumowując tę część rozważań należy podkreślić, że hipertrofię turystyki miejskiej konstytuuje wiele zjawisk i relacji, często sprzężeń zwrotnych, które wynikają ze złożonej natury miasta, jak i złożonej natury turystyki. Jednak najbardziej nagłaśniane są faktyczne lub percepowane koszty społeczne (które, parafrazując Baumana, są skutkami ubocznymi opisywanej miejskiej zmiany), stanowiące zarazem trzon naukowej i publicznej aktualnej debaty nad turystyką w miastach.

\section{PODSUMOWANIE}

Artykuł przedstawia autorskie ujęcie hipertrofii turystyki miejskiej, jak i bezpośrednią oraz kontekstową genezę tego zjawiska. Pokazana w artyku- 
le logika włączania i wykorzystywania turystyki $\mathrm{w}$ transformacji miejskiej gospodarki i przestrzeni oraz przypisane jej role $\mathrm{w}$ polityce miejskiej odsłaniają wielowymiarowe zależności między miastem a turystyką. Otrzymany obraz jest wysoce złożony i turbulentny, a zarazem ambiwalentny (bądź przynajmniej trudny w ocenie). Przywołane koncepcje i wzorce zmian wyjaśniają m.in. zaangażowanie sektora publicznego we wspieranie rozwoju podaży turystycznej i podnoszenie atrakcyjności turystycznej miejskiej przestrzeni (zwłaszcza przez rewitalizację centrów). Wskazano również obecne w różnych kontekstach geograficznych procesy i zjawiska towarzyszące turystyfikacji miasta, w tym zyskującą na znaczeniu finansjalizację zasobów mieszkaniowych.

Prowadzone rozważania stanowily punkt wyjścia do przedstawienia hipertrofii turystyki miejskiej określającej stan, który dotyka coraz więcej miast, zwłaszcza europejskich. Przedstawione autorskie (jeszcze nie w pełni ustrukturyzowane) ujęcie hipertrofii turystyki miejskiej jest próbą odpowiedzi na wskazaną przez Domańskiego (2017) potrzebę poszukiwania nowych koncepcji teoretycznych, umożliwiających rozpoznawanie pojawiających się procesów społeczno-gospodarczych z wyprzedzeniem. Coraz bardziej kontestowana turystyfikacja miasta (w polskiej literaturze por. m.in.: Hausner, 2016; Kubicki, 2017; Nowak, 2015; Purchla, 2018) wydaje się warta takiej refleksji, zwłaszcza w warunkach polskich miast prezentujących leseferystyczne podejście do rozwoju turystyki. Autorka, jakkolwiek przytacza częstokroć obecny w literaturze krytyczny stosunek do rozwoju turystyki miejskiej, stoi na stanowisku zbieżnym ze zdaniem Żabińskiej (2013), że turystyka „może spełniać ważną funkcję gospodarczą w przypadku dużych miast i metropolii, być czynnikiem rewitalizacji miast i ich dzielnic, ale strategie jej rozwoju muszą podporządkować się nadrzędnemu celowi, jakim jest wzrost dobrobytu i jakości życia mieszkańców" (2013, s. 153). Potrzeba zatem wiedzy na temat społecznych następstw i percepcji skutków rozwoju turystyki miejskiej, by móc racjonalnie dyskutować nad potrzebami i oczekiwaniami stałych mieszkańców, biznesu i turystów. Zajmowanie się hipertrofią turystyki miejskiej, której symptomy zdają się ujawniać w polskich miastach, należałoby więc motywować zarówno względami teoretycznymi, jak i aplikacyjnymi.

Podsumowując trzeba wskazać, że geneza hipertrofii turystyki miejskiej obejmuje znacznie więcej aspektów, w tym związanych $\mathrm{z}$ modernizacją współczesnych społeczeństw, przemianami, jakim podlega sama turystyka, czy odmiennością środowisk miejskich. W artykule skupiono się na wybranych zagadnieniach, które w perspektywie ogólnej można potraktować jako miejskie uwarunkowania analizowanego fenomenu.

\section{PRZYPISY}

${ }^{1}$ Na potrzeby tej pracy przyjmuję za Lewickim (2014, s. 146), że finansjalizacja jest „procesem przeniesienia zarządzania sprawami gospodarczymi i społecznymi do sfery rynkowej, w której poczesną rolę odgrywają rynki finansowe". Zdaniem Christophers'a (2015), termin ten zwłaszcza w badaniach ekonomiczno-politycznych zastępuje wcześniejsze koncepcje, takie jak neoliberalizm czy globalizacja. Jednak $\mathrm{w}$ literaturze nie ma zgodności w tej kwestii. Debata miejska ma zwłaszcza problemy z konceptualizacją związku finansjalizacji i neoliberalizmu (Aalbers, 2019a).

Stale rosnące znaczenie wpływu finansjalizacji na współczesne miasto podkreśliły m.in.: tematyka, prace oraz dyskusje prowadzone podczas konferencji Komisji Geografii Miast podczas MUG 2019 w Luksemburgu.

${ }^{2}$ Mimo że globalizacja nie jest procesem nowym (niektórzy upatrują jej pierwszej fazy w odkryciach geograficznych, drugiej w rewolucji przemysłowej), to niewątpliwe przyspieszenie tempa procesów globalizacyjnych nastąpiło $\mathrm{w}$ dwóch ostatnich dekadach XX w. (Alejziak, Szczechowicz, 2019; Czerny, 2005).

${ }^{3}$ Do polskiego piśmiennictwa termin ten wprowadziła Dziegieć (1995, s. 14), definiując 'turystyfikację' jako „proces przystosowania przestrzeni do potrzeb turystyki". Termin ten jest ugruntowany w głównym nurcie anglojęzycznej literatury z zakresu nauk o turystyce (począwszy od Jansen-Verbeke, 1998). Ogniskuje on zwłaszcza trwającą od dekad dyskusję wokół procesów wpływu turystyki na zasoby kulturowe. Miejski kontekst turystyfikacji wprowadzono wraz $\mathrm{z}$ badaniami nad miastami historycznymi. Renesans zainteresowania turystyfikacją przypada na ostatnie lata i związany jest ze wzrostem turystyki miejskiej i społeczną jej kontestacją. W tym ostatnim społecznym kontekście termin ten jest coraz częściej dyskutowany w studiach miejskich - por. Kowalczyk-Anioł (2019).

${ }^{4}$ Podobne zmiany można wskazać $\mathrm{w}$ mieście przełomu XIX/XX w., jednak tworzona wówczas oferta była skierowana do ówczesnych elit, podczas gdy koniec XX w. charakteryzuje ukierunkowanie na masowego odbiorcę.

${ }^{5}$ Jednocześnie, jak konstatuje Sagan (2017), inicjująca i kluczowa rola sektora publicznego $\mathrm{w}$ procesach rewitalizacyjnych kształtuje ich silnie pragmatyczno-polityczny wymiar i kadencyjny charakter.

${ }^{6}$ Wprowadzona po 2009 r. nowa neoliberalna polityka przestrzenna i turystyczna $\mathrm{w}$ Hiszpanii ( $\mathrm{w}$ tym podkreślona potrzeba inwestycji prywatnych finansowanych przez korporacje hotelowe - Yrigoy, 2016) przyniosła nowe regulacje, które pobudzily inwestycje kapitałowe m.in. przez usprawnienia procedur administracyjnych w projektach miejskich (Blazquez-Salom, Blaneo-Romero, Vera-Rebollo, Ivars-Baidal, 2019).

7 Tak zwana gospodarka współdzielenia (sharing economy) to model nieodpłatnej (np. w formie klubowej jak couchsurfing - Kowalczyk-Anioł, 2011) lub odpłatnej (np. Airbnb, HomeAway) wymiany usług pomiędzy indywidualnymi osobami 
(relacje peer-to-peer (P2P), czyli między indywidualnymi osoba$\mathrm{mi})$ koordynowany przez specjalne serwisy internetowe. Największym globalnym pośrednikiem jest komercyjna platforma Airbnb, która zajmuje się pośrednictwem w turystycznym krótkoterminowym najmie miejsca $\mathrm{w}$ pokoju, pokoju w mieszkaniu lub całego prywatnego mieszkania.

Współcześnie w odniesieniu do krótkoterminowego najmu turystycznego coraz częściej podnoszone są zarzuty tzw. pseudowspółdzielenia (pseudo-sharing - Belk, 2014), bowiem oferty $\mathrm{w}$ atrakcyjnych lokalizacjach udostępnione przez komercyjne platformy, zwłaszcza Airbnb, dotyczą przeważnie całych mieszkań, a ich gospodarze (np. około $60 \%$ ogłaszających z Barcelony, Hong Kongu, czy Rzymu) skupiają w swoim portfelu wiele nieruchomości (por. Adamiak, 2018; Pawlicz, 2019).

8 O możliwościach, jakie stwarza mieszkańcom miast sieciowa współpraca wychodząca znacznie poza skierowane do turystów udostępnianie zasobów mieszkaniowych pisze Brzozowska (2017).

${ }^{9}$ Obserwacja oferty i oferentów Airbnb pokazuje, że w wielu miastach turystycznych uwidacznia się dążenie do zastępowania mieszkańców i lokalnych właścicieli, najpierw inwestorami zagranicznymi a później korporacyjnymi, zaś turystów szukających atrakcyjnej cenowo oferty zamożniejszą klientelą (por. m.in. Cocola-Gant, Gago, 2019).

${ }^{10}$ Autorzy twierdzą, że obserwowany w Lizbonie modus operandi, w którym mieszkania czynszowe stały się nowym aktywem finansowym (w następstwie kryzysu gospodarczego $\mathrm{z}$ roku 2008) jest bezpośrednio związany $\mathrm{z}$ działalnością platformy Airbnb, która odpowiada za globalny wzrost rynku krótkoterminowego najmu turystycznego (Adamiak, 2018). Podkreślają też, że inwestycje w wynajem mieszkań są coraz bardziej elastyczne $\mathrm{i}$ wydajne.

${ }^{11} \mathrm{O}$ dziedzictwie muzycznym Lizbony, w tym casas de fado, pisze szerzej Golemo (2016).

12 Rozumianą, za Pawlusińskim i Zmyślonym (2018, s. 7), jako „ogół działalności społecznych i ekonomicznych podejmowanych przez różne podmioty w porze nocnej" i której zasadniczym elementem jest „nocna konsumpcja wolnoczasowa”, wrastająca coraz silniej w ofertę kulturowa miast (Zukin, 2009).

13 Ogłoszonej przez Lonely Planet najlepszym miastem do odwiedzin w 2018 r., a Airbnb jedną z najlepszych destynacji dla 2019 r.

14 Russo i Scarnato (2018) upatrują programowość takich działań w tzw. dyskursie globalnej maszyny wzrostu turystyki.

15 Człon hiper- (z gr. hypér - „nad”) znaczy: „zbyt dużo, szkodliwy nadmiar, przesada w czymś".

16 Wśród innych stanów niezrównoważenia miasta można m.in. wskazać miasto pod presją niekontrolowanego napływu imigrantów, czy miasto zmagające się z epidemią śmiercionośnego wirusa. Stany te radykalnie redefiniują organizację życia i przestrzeni w mieście

17 Jakkolwiek można mówić o miastach opuszczonych z różnych przyczyn przez mieszkańców, a obecnie użytkowanych jedynie przez turystów, np. prekolumbijskim porzuconym przez Majów Chichén Itzá, inkaskim Machu Picchu czy opuszczonej po czarnobylskiej katastrofie nuklearnej Prypeci.

18 Wypowiedź zawarta w ramach publikacji: „Panel ekonomiczno-planistyczny nt. Współczesny rozwój miast - forma, funkcje i zarządzanie" (2014).

19 Prawo do miasta jest szeroko dyskutowaną ideą. Jest zarazem częścią debaty nad problemami i wyzwaniami współczesnego miasta, której jednak autorka nie podejmuje się rozwijać w tym artykule poprzestając jedynie na naturalnej bliskości poruszanych kwestii.

\section{BIBLIOGRAFIA}

Aalbers, M.B. (2019a). Housing and financialization. W: M. Moos (red.), A research agenda for housing (s. 31-46). Cheltenham: Edward Elgar Publishing.

Aalbers M.B. (2020). Financial geography III: The financialization of the city. Progress in Human Geography, 44 (3), s. 595-607.

Adamiak, C. (2018). Mapping Airbnb supply in European cities. Annals of Tourism Research, 71, s. 67-71.

Alejziak, W., Szczechowicz, B. (2019). Globalizacja a rozwój turystyki - implikacje dla planowania i polityki turystycznej. W: Z. Młynarczyk, A. Zajadacz (red.). Uwarunkowania i plany rozwoju turystyki. Planowanie i polityka turystyczna (s. 9-27). Poznań: Bogucki Wydawnictwo Naukowe.

Amore, A. (2019). Tourism and urban regeneration: Processes compressed in time and space. London: Routledge.

Arbaci, S., Tapada-Berteli, T. (2012). Social inequality and urban regeneration in Barcelona city centre: reconsidering success. European Urban and Regional Studies, 19 (3), s. 287-311.

Belk, R. (2014). Sharing versus pseudo-sharing in Web 2.0. The Anthropologist, 18 (1), s. 7-23.

Bianchini, F. (1993). Remaking European cities: The role of cultural politics. W: F. Bianchini, M. Parkinson (red.), Cultural policy and urban regeneration: The West European experience (s. 1-20). Manchester: Manchester University Press.

Bianchini, F., Dawson, J., Evans, R. (1992). Flagship projects in urban regeneration. W: P. Healey (red.), Rebuilding the city: Property-led urban regeneration (s. 245-255). London: Chapman \& Hall

Blázquez-Salom, M., Blanco-Romero, A., Vera-Rebollo, F., Ivars-Baidal, J. (2019). Territorial tourism planning in Spain: from boosterism to tourism degrowth? Journal of Sustainable Tourism, 27 (12), s. 1764-1785.

Bourdeau, P., François, H., Bensahel, L. (2013). Fin (?) et confins du tourisme: interroger le statut et les pratiques de la récréation contemporaine. Paris: L'Harmattan.

Błaszczyk, M. (2015). Miejski system okazji i jego użytkownicy. Przestrzeń Spoteczna, 1, s. 111-138.

Bradley, A., Hall, T., Harrison, M. (2002). Selling cities: promoting new images for meetings tourism. Cities, 19 (1), s. 61-70.

Brzozowska, B. (2017). Miejskie ttumy: miasto i wspólnotowość w dobie sieciowej wspótpracy. Łódź: Wyd. Uniwersytetu Łódzkiego.

Christophers, B. (2015). The limits to financialization. Dialogues in Human Geography, 5 (2), s. 183-200.

Clark, T.N., Lloyd, R., Wong, K.K., Jain, P. (2002). Amenities drive urban growth. Journal of Urban Affairs, 24 (5), s. 493-515.

Cocola-Gant, A., Gago, A. (2019). Airbnb, buy-to-let investment and tourism-driven displacement: A case study in Lisbon. Environment and planning A: Economy and space, https:// doi.org/10.1177/0308518X19869012

Colomb, C., Novy, J. (red.) (2017). Protest and resistance in the tourist city. London: Routledge.

Cook, A. (2010). The expatriate real estate complex: Creative destruction and the production of luxury in post-socialist Prague. International Journal of Urban and Regional Research, 34 (3), s. 611-628.

Czerny, M. (2005). Globalizacja a rozwój: wybrane zagadnienia geografii społeczno-gospodarczej świata. Warszawa: Wydawnictwo Naukowe PWN.

Darchen, S. (2013). The regeneration process of entertainment zones and the business improvement area model: A comparison between Toronto and Vancouver. Planning Practice $\mathcal{E}$ Research, 28 (4), s. 420-439.

Domański, R. (2017). Złożoność przestrzeni ekonomicznej. Studia KPZK, 178, s. 47-73. 
Dziedzic, E. (2012). Zaangażowanie finansowe sektora publicznego w rozwój podaży turystycznej w miastach. Studia Ekonomiczne, 119, s. 33-44.

Dziegieć, E. (1995). Urbanizacja turystyczna terenów wiejskich w Polsce. Turyzm, 5 (1), s. 5-56.

Eisinger, P. (2000). The politics of bread and circuses: Building the city for the visitor class. Urban Affairs Review, 35 (3), s. 316-333.

Golemo, K. (2016). Zwiedzanie dźwiękami. Muzyczne podróże po Lizbonie. Folia Turistica, 39, s. 171-198.

González, S. (2011). Bilbao and Barcelona 'In motion'. How urban regeneration 'models' travel and mutate in the global flows of policy tourism. Urban Studies, 48 (7), s. 1397-1418.

Gotham, K.F. (2005). Tourism gentrification: The case of New Orleans' Vieux Carre (French Quarter). Urban Studies, 42 (7), s. 1099-1121.

Gravari-Barbas, M. (2017). Super-gentrification and hypertourismification in Le Marais, Paris. W: M. Gravari-Barbas, S. Guinand (red.), Tourism and gentrification in contemporary metropolises: International perspectives (s. 299-328). London: Taylor \& Francis.

Gravari-Barbas, M., Jacquot, S. (2019). Mechanisms, actors and impacts of the touristification of a tourism periphery: the Saint-Ouen flea market, Paris. International Journal of Tourism Cities, 5 (3), s. 370-391.

Hall, C.M. (2006). Urban entrepreneurship, corporate interests and sports megaevents: The thin policies of competitiveness within the hard outcomes of neoliberalism. The Sociological Review, 54 (2), s. 59-70.

Hall, C.M. (2008). Tourism planning: Policies, processes and relationships. Harlow: Prentice Hal.

Hall, P. (1993). Forces shaping urban Europe. Urban Studies, 30 (6), s. 883-898.

Harvey, D. (1989). From managerialism to entrepreneurialism: the transformation in urban governance in late capitalism. Geografiska Annaler: Series B. Human Geography, 71 (1), s. 3-17.

Hausner, J. (2016). Miasto - idea i rola kultury w jego rozwoju. Kultura i Rozwój, 1 (1), s. 109-122.

Hiller, H.H. (2000). Mega-evants, urban boosterism and growth strategies: an analysis of the objectives and legitimations of the Cape Town 2004 Olympic Bid. International Journal of Urban and Regional Research, 24 (2), s. 449-458.

Hoffman, L., Fainstein, S., Judd, D. (red.) (2003). Cities and visitors. Regulating people, markets and city space. Oxford: Blackwell.

Hubbard, P. (1996). Urban design and city regeneration: social representations of entrepreneurial landscapes. Urban Studies, 33 (8), s. 1441-1461.

Hughes, G. (1999). Urban revitalization: The use of festive time strategies. Leisure Studies, 18 (2), s. 119-135.

Ioannides, D., Röslmaier, M., van der Zee, E. (2019). Airbnb as an instigator of 'tourism bubble' expansion in Utrecht's Lombok neighbourhood. Tourism Geographies, 21 (5), s. 822-840.

Jansen-Verbeke, M. (1998). Tourismification of historical cities. Annals of Tourism Research, 25 (3), s. 739-742.

Jansen-Verbeke, M. (2009). The territoriality paradigm. W: cultural tourism. Tourism, 19 (1-2), s. 25-31.

Jessop, B. (2015). Wprowadzenie do: Od menedżeryzmu do przedsiębiorczości: transformacja procesu rządzenia miastami w późnym kapitalizmie, Zarządzanie Publiczne, 33 (3), s. 84-87. https: / / www.ceeol.com/search/article-detail?id=397749

Jover, J., Díaz-Parra, I. (2020). Who is the city for? Overtourism, lifestyle migration and social sustainability. Tourism Geographies, 1-24. https://doi.org/10.1080/14616688.2020.1713878
Judd, D.R. (1999). Constructing the tourist bubble. W: D.R. Judd, S.S. Fainstein (red.), The tourist city (s. 35-53). New Haven: Yale University Press.

Judd, D.R. (2015). The infrastructure of play: Building the tourist city. London: Routledge.

Kaczmarek, J. (2010). Zarządzanie wizerunkiem miasta - uwagi heurystyczne. Studia Miejskie, 1, s. 29-38.

Karczmarek, T. (2001). Rewitalizacja miast w Polsce na tle doświadczeń europejskich. W: A. Billert (red.), Nowoczesne zarządzanie rozwojem miast. Stubice: Collegium Polonicum UAM Poznań w Słubicach.

Kaczmarek, S. (1999). Tourism and urban revitalisation. European Spatial Research and Policy, 6 (1), s. 99-104.

Keil, R. (2009). The urban politics of roll-with-it neoliberalization. City, 13 (2-3), s. 230-245.

Kowalczyk-Anioł, J. (2011). Kluby wzajemnej gościnności - signum temporis współczesnej turystyki polskiej młodzieży. W: A. Stasiak (red.), Perspektywy $i$ kierunki rozwoju turystyki spotecznej w Polsce (s. 141-156). Łódź: Wyd. Wyższej Szkoły Turystyki i Hotelarstwa.

Kowalczyk-Aniol, J. (2018). Koncepcja gentryfikacji turystycznej i jej współczesne rozumienie. Prace Geograficzne, 154, s. 35-54.

Kowalczyk-Anioł, J. (2019). Tourismification of the housing resources of historical inner cities. The case of Kraków. Studia Miejskie, 35, s. 9-25.

Kowalczyk-Anioł, J., Włodarczyk, B. (2017). Przestrzeń turystyczna przestrzenią konfliktu. Prace $i$ Studia Geograficzne, $62(2)$, s. 55-73.

Kowalczyk-Anioł, J., Zmyślony, P. (2017). Turystyka miejska jako źródło protestów społecznych: przykłady Wenecji i Barcelony. Turystyka Kulturowa, 2, s. 7-36.

Kruczek, Z. (2018). Turyści vs. mieszkańcy. Wpływ nadmiernej frekwencji turystów na proces gentryfikacji miast historycznych na przykładzie Krakowa. Turystyka Kulturowa, 3, s. 29-41.

Kubicki, P. (2017). Wpływ studentyfikacji i turystyfikacji na społeczno-kulturową przestrzeń miasta. Miasto. Pamięć i Przyszłość, 2, s. 63-73.

Lestegás, I., Seixas, J., Lois-González, R.C. (2019). Commodifying Lisbon: A study on the spatial concentration of short-term rentals. Social Sciences, 8 (2), 33.

Lewicki, M. (2014). „Za mała, by sfinansjalizować?”. Procesy finansjalizacji i polska gospodarka. Prakseologia, 155, s. 125-173.

Lloyd, R., Clark, T.N. (2001). The city as an entertainment machine. W: K.F. Gotham (red.), Critical perspectives on urban redevelopment. Research in urban sociology (s. 357-378). Oxford: JAIPress/Elsevier.

Lowe, M. (2005). The regional shopping centre in the inner city: A study of retailled urban regeneration. Urban Studies, 42 (3), s. $449-470$

Lucarelli, A., Berg, P.O. (2011). City branding: A state-of-the-art review of the research domain. Journal of Place Management and Development, 4 (1), s. 9-27.

Madurowicz, M. (2017). Ciagtość miasta. Prolegomena. Warszawa: Wydawnictwa Uniwersytetu Warszawskiego.

Maitland, R., Newman, P. (2014). World tourism cities: Developing tourism off the beaten track. London: Routledge.

Martinotti, G. (1993). Metropoli: La nuova morfologia sociale della città. Bolonia: Il Mulino.

Morell, M. (2009). Fent barri: heritage tourism policy and neighbourhood scaling in Ciutat de Mallorca. Etnográfica. Revista do Centro em Rede de Investigação em Antropologia, 13 (2), s. $343-372$.

Mullins, P. (1991). Tourism urbanization. International Journal of Urban and Regional Research, 15 (3), s. 326-342. 
Murzyn, M. (2006). Kazimierz. Środkowoeuropejskie doświadczenie rewitalizacji. Kraków: Międzynarodowe Centrum Kultury.

Murzyn-Kupisz, M. (2012). Cultural, economic and social sustainability of heritage tourism: Issues and challenges. Economic and Environmental Studies, 12 (2), s. 113-133.

Nowak, M. (2015). Mieszkaniec a użytkownik zewnętrzny - perspektywa krytyczna. Rozwój Regionalny i Polityka Regionalna, s. 7-16.

Panel ekonomiczno-planistyczny nt. Współczesny rozwój miast - forma, funkcje i zarządzanie. (2014). W: M. Madurowicz (red.), Ksztattowanie wspótczesnej przestrzeni miejskiej (s. 613633), Warszawa: Wydawnictwa Uniwersytetu Warszawskiego.

Park, H.Y. (2013). Heritage tourism. Abingdon: Routledge.

Parysek, J.J. (2015). Miasto w ujęciu systemowym. Ruch Prawniczy, Ekonomiczny i Socjologiczny, 77 (1), s. 27-53.

Paskaleva-Shapira, K.A. (2007). New paradigms in city tourism management: Redefining destination promotion. Journal of Travel Research, 46 (1), s. 108-114.

Pawlicz, A. (2019). Ekonomia wspótdzielenia na rynku ustug hotelarskich. Niedoskonatości. Pośrednicy. Regulacje. Szczecin: Wyd. Naukowe Uniwersytetu Szczecińskiego.

Pawlusiński, R. (2017). Ekonomia współdzielenia: istota zjawiska oraz wyzwania dla sektora turystyki $\mathrm{w}$ miastach W: M. Drewnik, M. Mika (red.) Człowiek i jego dziatania. Spojrzenie geografa. Prace dedykowane Profesorowi Wtodzimierzowi Kurkowi (s. 179-191). Kraków: Instytut Geografii i Gospodarki Przestrzennej Uniwersytetu Jagiellońskiego.

Pawlusiński, R., Zmyślony, P. (2018). Gospodarka nocna a oferta kulturowa miast. Turystyka Kulturowa, 7, s. 7-22.

Peeters, P., Gössling, S., Klijs, J., Milano, C., Novelli, M., Dijkmans, C., Eijgelaar, E., Hartman, S., Heslinga, J., Isaac, R., Mitas, O., Nawijn, J., Papp, B., Postma, A. (2018), Research for the TRAN Committee - Overtourism: impact and possible policy responses, European Parliament, Policy Department for Structural and Cohesion Policies, Brussels.

Pinkster, F.M., Boterman, W.R. (2017). When the spell is broken: Gentrification, urban tourism and privileged discontent in the Amsterdam canal district. Cultural Geographies, 24 (3), s. $457-472$

Purchla, J. (2018). Miasto i polityka: przypadki Krakowa. Kraków: Universitas.

Richards, G. (1996). Production and consumption of European cultural tourism. Annals of Tourism Research, 23 (2), s. 261-283.

Richards, G., Wilson, J. (2006). The creative turn in regeneration: Creative spaces, spectacles and tourism in cities. W: M.K. Smith (red.), Tourism, culture and regeneration (s. 12-24). Wallingford: CABI.

Russo, A.P., Scarnato, A. (2018). "Barcelona in common": A new

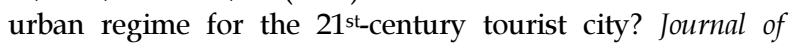
Urban Affairs, 40 (4), s. 455-474.

Sagan, I. (2017). Miasto: nowa kwestia i nowa polityka. Warszawa: Wyd. Naukowe Scholar.
Salah Ouf, A.M. (2001). Authenticity and the sense of place in urban design. Journal of Urban Design, 6 (1), s. 73-86.

Sassen, S. (2007). Globalizacja. Eseje o nowej mobilności ludzi i pieniędzy, Kraków: Wyd. UJ.

Scott, A.J. (1997). The cultural economy of cities. International Journal of Urban and Regional Research, 21 (2), s. 323-339.

Scott, A.J. (2000). The cultural economy of cities: essays on the geography of image-producing industries. Sage.

Selby, M. (2004). Consuming the city: conceptualizing and researching urban tourist knowledge, Tourism Geographies, 6 (2), s. 186-207.

Sharpley, R. (2018). Tourism, tourists and society. London: Routledge.

Smith, A. (2012). Events and urban regeneration: The strategic use of events to revitalise cities. London: Routledge.

Smith, M.K. (2006). Towards a cultural planning approach to regeneration. W: M.K. Smith (red.), Tourism, culture and regeneration (s. 1-11). Wallingford: CABI.

Smith, N. (1986). Gentrification, the frontier and the restructuring of urban space. W: N. Smith, P. Williams (red.), Gentrification of the city (s. 15-34). London: Allen \& Unwin.

Smith, N. (2005). The new urban frontier: Gentrification and the revanchist city. New York: Routledge.

Soja, E.W. (2004). Urban tensions: Globalization, economic restructuring, and the posmetropolitan transition. W: L. Beneria, S. Bosnath (red.). Challenges and opportunities in the word economy (s. 275-290). New York: Routledge.

Spirou, C. (2011). Urban tourism and urban change: Cities in a global economy. New York: Routledge.

Stanilov, K. (2007). The post-socialist city: Urban form and space transformations in Central and Eastern Europe after socialism. Berlin: Springer Science \& Business Media.

Stryjakiewicz, T. (2010). Krajobraz antropogeniczny, przestrzenie kreatywne a turystyka. Prace Komisji Krajobrazu Kulturowego, 14, s. 52-62.

UNWTO (2012). Global report on city tourism - Cities 2012. Project. Madrit: UNWTO.

UNWTO (2019). Global report on city tourism - Cities 2019. Project. Madrit: UNWTO.

Vives Miró, S. (2011). Producing a "successful city": Neoliberal urbanism and gentrification in the tourist city - The case of Palma (Majorca). Urban Studies Research, s. 1-13.

Wachsmuth, D., Weisler, A. (2018). Airbnb and the rent gap: Gentrification through the sharing economy. Environment and Planning A: Economy and Space, 50 (6), s. 1147-1170.

Yrigoy, I. (2016). Financialization of hotel corporations in Spain. Tourism Geographies, 18 (4), s. 399-421.

Zukin, S. (2009). Naked city: The death and life of authentic urban places. New York: Oxford University Press.

Żabińska, T. (2013). Turystyka w dużych miastach i metropoliach. Wybrane problemy rozwoju i zarządzania. Studia Ekonomiczne, 147, s. 133-153.

Artykuł wpłyną 27 marca 2019

Zaakceptowano do druku: 6 grudnia 2019 